\title{
Floral morphology and chromosome characteristics of bamboo orchid from Menoreh Hills, Kulonprogo
}

\author{
F. Y. Kurniawan ${ }^{1,3}$ and E. Semiarti ${ }^{2 *}$ \\ Received: 21 $1^{\text {st }}$ August 2020 / Accepted: $04^{\text {th }}$ August 2021
}

\begin{abstract}
Purpose: One of the most common orchids in Menoreh Hills, Kulonprogo is bamboo orchids (Arundina). This genus has only one species but has a wide variety of flower phenotypic that spreads around the world. The aims of this research were to characterize the flower morphology and chromosome content of bamboo orchids from Menoreh, related to their taxonomic status.
\end{abstract}

Research Method: Observation of morphological characters was carried out to assist the identification process of the bamboo orchid species. The squashing method is used in the preparation of bamboo orchid chromosomes. The results were analyzed with Image Raster 3.0, Corel Draw 11 and Ms. Excel 2010.

Findings: Bamboo orchid from Menoreh, Kulonprogo is a flower with white sepals and petals, the tips of sepals are yellowish brown. Labellum is white, with a thin purple stripe on the edges, and the base is yellow. Chromosomes number $2 n=20$, with the formula karyotype $2 n=2 x=20=16 \mathrm{~m}+4 \mathrm{sm}$. Chromosomes' absolute length is 0.55-1.64 $\mu \mathrm{m}$ and relative lengths 0.57-1.615 $\mu \mathrm{m}$. Based on morphological characters, Menoreh's bamboo orchid has similarities with A. graminifolia, whereas based on chromosomes number and karyotype formula, it is different.

Limitations: There are bamboo orchids with a wide variety of flowers around world. However, the sample collection is only limited to bamboo orchid in Purwosari village, Kulonprogo.

Value: Menoreh's bamboo orchid has a potential to be a new variant from the A. graminifolia population, based on the differences in morphological and chromosomal characters.

Keywords: Bamboo orchids, Chromosomes, Karyotype, Kulonprogo, Morphology, Taxonomy

\section{INTRODUCTION}

Family Orchidaceae consists of 20,000-25,000 species (Fajriyah, 2011), 10\% of the total Angiospermae members in the world with a wide distribution (Swarts and Dixon, 2009). Indonesia has $\pm 5,000$ species of orchids (Setiaji et al., 2018), with \pm 731 species found on Java (Comber, 1990). Special Region of Yogyakarta has $16.14 \%$ of the total orchid species in Java (Setiaji et al., 2018). The high diversity of orchid species appeared due to phenotype variation. Phenotype characters arise from interactions between genotypes and environmental factors (Meena et al., 2019).

Based on the life form, epiphytic and terrestrial orchids are the most abundant in Yogyakarta. One of the most popular orchids found in the districts of Kulonprogo and Sleman is bamboo orchid (Arundina graminifolia). This orchid can be found on a cliff and near the road (Setiaji et al., 2018). Arundina, is one of the orchid genera with a single member, namely $A$. graminifolia (Kumar et al., 2014). It has a single member but in one population, there can still be found variations, especially in flower patterns and

1 Study Program of Biotechnology, Graduate School, Universitas Gadjah Mada, Teknika Utara street, Pogung, Mlati, Sleman 55281, D. I. Yogyakarta, Indonesia.

2 Department of Tropical Biology, Faculty of Biology, Universitas Gadjah Mada, Teknika Selatan street, Sekip Utara, Bulaksumur, Depok, Sleman 55281, D. I. Yogyakarta, Indonesia.

3 Biology Orchid Study Club (BiOSC), Faculty of Biology, Universitas Gadjah Mada, Teknika Selatan street, Sekip Utara, Bulaksumur, Depok, Sleman 55281, D. I. Yogyakarta, Indonesia.

endsemi@ugm.ac.id

https://orcid.org/0000-0001-7723-2705 
colors. This orchid has a habitus that resembles weeds, so that sometimes it is often considered a pest by human and pruned. When the flowering period occurs, this orchid is recognized, because of its attracted color among a population of tall grass. This population of orchids is often found along Menoreh Hills, Kulonprogo.

Cytogenetic studies (chromosomes) can be used as a reference in taxonomy and evolution (Crowder, 1990). Previous cytogenetic studies on $A$. graminifolia revealed that the species had a chromosome number $2 \mathrm{n}=40$ (Lee, 1987). Based on observations of the phenotypic character of bamboo orchids from the Menoreh Hills, Kulonprogo some differences of literature are noted, and especially, in flowers. This variation also appears in these species in several countries in the world. This study aims to characterize the bamboo orchid samples found in Menoreh Hills, Kulonprogo through their morphological and cytogenetic characters. The characters obtained can also be used to reveal the taxonomic status of the bamboo orchids found in Menoreh.

\section{MATERIALS AND METHODS}

The research was conducted in October to December 2019. The material used were the young roots of bamboo orchid (3-4 years) with a length $\pm 1 \mathrm{~cm}$. Bamboo orchids collected from Purwosari village, Girimulyo District, Kulonprogo Regency, Special Region Yogyakarta, Indonesia (744'02.3"S; $110^{\circ} 08^{\prime} 03.9^{\prime \prime} \mathrm{E} ; 778 \mathrm{~m}$ asl). The reagents used in chromosome preparation consist of $45 \%$ glacial acetic acid (GAA); hydrochloric acid $(\mathrm{HCl}) 1 \mathrm{~N}$; Feulgen; aquades; and glycerin. The tools used include $1,5 \mathrm{~mL}$ microtube; refrigerators, block heaters, glass objects, glass covers, dropper pipettes, brushes, razor blades, pens, light microscopes and optilab.

\section{Observation of Morphological Characters}

Observation of morphological characters includes roots, stem classification, stem habitus, arrangement of leaves, leaf shape, leaf tip, leaf base, leaf edge, leaf venation, flower type, fruit and seed characters. Determination of morphological characters is assisted with Taxonomy of Vascular Plants literature (Lawrence, 1968) and Characterization Guidelines for Ornamental Plants: Orchid literature (BPTH, 2007). Based on the morphological characters obtained, they were matched with the book of orchid flora namely Orchids of Java (Comber, 1990) for the identification process. In addition, literature studies from several journals was also carried out to compare the variation of flowers in bamboo orchid populations in various regions.

\section{Chromosome Preparation}

The plant chromosome preparation method used is the squashing method Nathewet et al. (2009) that has been modified.

\section{Root Tip Cutting}

Orchid roots were cleaned from the attached soil. Young roots were selected with white or transparent, small and thick characteristics. Roots that used have a length $\pm 1-2 \mathrm{~cm}$. At 09.00 $\mathrm{AM}$, the root tip was cut with a size of $0.5-1 \mathrm{~cm}$.

\section{Root Tip Fixation}

Root tip already cut was inserted into a 1.5 $\mathrm{mL}$ microtube and added AAG $45 \% 0.5 \mathrm{~mL}$ until the root tip was completely submerged. Microtube was put into the refrigerator at $4^{\circ} \mathrm{C}$ for \pm 20 minutes.

\section{Maceration}

Glacial acetic acid (GAA) was sucked with a dropper pipette. Root tip washed with aquades three times. Samples were added with 0.5 $\mathrm{mL} 1 \mathrm{~N} \mathrm{HCl}$ until the tips of the roots were completely submerged. Microtube was put into a block heater, at $62^{\circ} \mathrm{C}$ for 30 minutes.

\section{Chromosome Staining}

Hydrochloric acid $(\mathrm{HCl})$ was sucked with a dropper pipette. Root tip washed with aquades three times. Samples were added with a 0.5 $\mathrm{mL}$ Fulgen solution and incubated at room temperature for 1 hour until the root tip turned purple. 


\section{Squashing, Observation and Photography}

The root tip was removed with the help of a brush and placed on a glass object. The root was cut $\pm 2 \mathrm{~mm}$ from the tip with purple color. The root tip was then dropped with glycerin and covered with a glass cover. The root tip then was pressed with the pen base slowly. The success parameter of the squeeze process is found, a purple thin layer and spread. Observation of preparations was carried out with light microscope and optilab with a magnification of $10 \times 40$. Captured image was focused on the prometaphase in the cell cycle.

\section{Data Analysis}

\section{Calculation the number of chromosomes}

The number of chromosomes can be determined through direct calculation of the number of chromosomes seen in the prometaphase with the help of Image Raster 3.0 and Corel Draw 11 for visualizing chromosome shapes.

2.Measurement of chromosome arm length, centromere index (CI) and determination of chromosome shape

Measurement of short arm length (p) and long arm length (q) for each chromosome is done with the help of Image Raster 3.0. The measurement results were analyzed with the help of Microsoft Excel 2010 to calculate CI values, determine the shape of chromosomes based on CI value, sorting chromosomes based on relative or absolute arm length $(\mathrm{p}+\mathrm{q})$ and determine chromosome shapes. In this study the
CI value is used as a reference in determining the shape of chromosomes (Table 01). The value of the centromere index $(\mathrm{CI})$ or numerical price of the centromere position (NPCP) is calculated according to the formula (1).

$$
\mathrm{CI}=\frac{(\text { short arm length }(\mathrm{p})}{\text { (relative or absolute length }(\mathrm{p}+\mathrm{q})} \times 100
$$

\section{Karyotype and Idiogram}

After chromosomes weree sorted, the short arm (p) and long arm (q) size data were used to make the idiogram. Idiograms were created with the help of Microsoft Excel 2010. Karyotype was created with the help of Corel Draw 11 by cutting chromosome images and sorting them based on CI values and their shape.

\section{RESULTS AND DISCUSSION}

Bamboo orchid found in Purwosari Village, Kulonprogo, which belongs to the Menoreh Hills, has a morphological character in the form of adventitious roots and the type of stem growth is sympodial. Habitus is classified as herbaceous plants, perennial, life form hemicriptophyte, terrestrial orchids, stem metamorphosis in the form of short, branched rhizomes, rhizomes forming buds, branching architecture of stem classified as tomlinson type. Erect stem branch, rigid, has a node and internodus with a distance of $\pm 7-10 \mathrm{~cm}$, cross section of the stem is circular with a diameter of $\pm 0.5-1 \mathrm{~cm}$ and the length can reach more than one meter (Figure $01 \mathrm{~A}$ ).

Table 01. Classification of chromosome shape based on centromere index value (CI) (Levan et al., 1964)

\section{Centromere Index}

Chromosome Shapes

Metacentric (m)

Submetacentric (sm)

Acrocentric/Subtelocentric (st)

Telocentric $(\mathrm{t})$ 
The leaves are classified as single leaf (folium simplex), leafy leaves, distichous phyllotaxis, linearis-ligulate/ ribbon leaf shape, length \pm $20 \mathrm{~cm}$, width $\pm 1-2 \mathrm{~cm}$, acute apex, perfoliatus base, entire/ integer leaf margin, rectinerve leaf nerve, conduplicate leaf cross section, convolute young leaf arrangement, glabrous/ bare leaf surface texture, symmetry of leaf tip symmetry. The capsule-shaped fruit is $\pm 5-6 \mathrm{~cm}$ long and $\pm 1 \mathrm{~cm}$ wide, has 3 true yellow ribs and 3 green false ribs (Figure $01 \mathrm{~B}$ ). The seeds are microscopic in size and have a flour-like texture.

Terminal flowering type, akrant flower stalks, raceme bouquets, lanceolate sepals, elliptic shaped petals, acute tip sepals, acuminate petal, trumpet shaped labellum/lip with bumpy edges. Flowers are predominantly white in the sepals and petals with a purple stripe in the middle, while brownish yellow is found at the end of the sepals. Labellum is dominated by white with a thin purple stripes pattern on the edge of the labellum. Yellow patterns are also found, but only at the base of the labellum with brownish red stripes. Simple bulge/ callus type in the labellum (Figure $01 \mathrm{C}$ ). Two yellow polinia.

Wild habitat of the bamboo orchid is on bush land and grassland with karst type soil substrate (Basri et al., 2019) and clay. This orchid lives associated with wild plants and weeds like Melastoma sp., Pennisetum sp., Lantana $s p$., Selaginella sp., and others. Based on the exploration results of the Biology Orchid Study Club (BiOSC) at 2015-2017 in Kulonprogo as well as the results of identification with the Orchid of Java literature (Comber, 1990), bamboo orchids found in Purwosari Village, Kulonprogo were identified as Arundina graminifolia species based on the morphological characters with similarity of vegetative organ, generative and habitus.

Based on 33 taxa in the world, only two taxa are officially accepted as members of the Arundina genera, namely Arundina graminifolia and Arundina graminifolia var. revoluta (Kumar et al., 2014). One of the main characters used in the process of identifying a species is the diversity of the flower structure as a generative/ reproductive organ. Differences and variations in morphological characters in flowers as reproductive organs, can lead to differences in the level of categories within taxa (Nuraliev et al., 2019). Differences in flower morphology lead to the successful reproduction and preservation of plants in nature (Herrera, 1995; Delgado-Davila et al., 2016). Arundina as genera with a single member, but in one species of $A$. graminifolia can be found in a variety of patterns and flower colors dispersed in different regions.

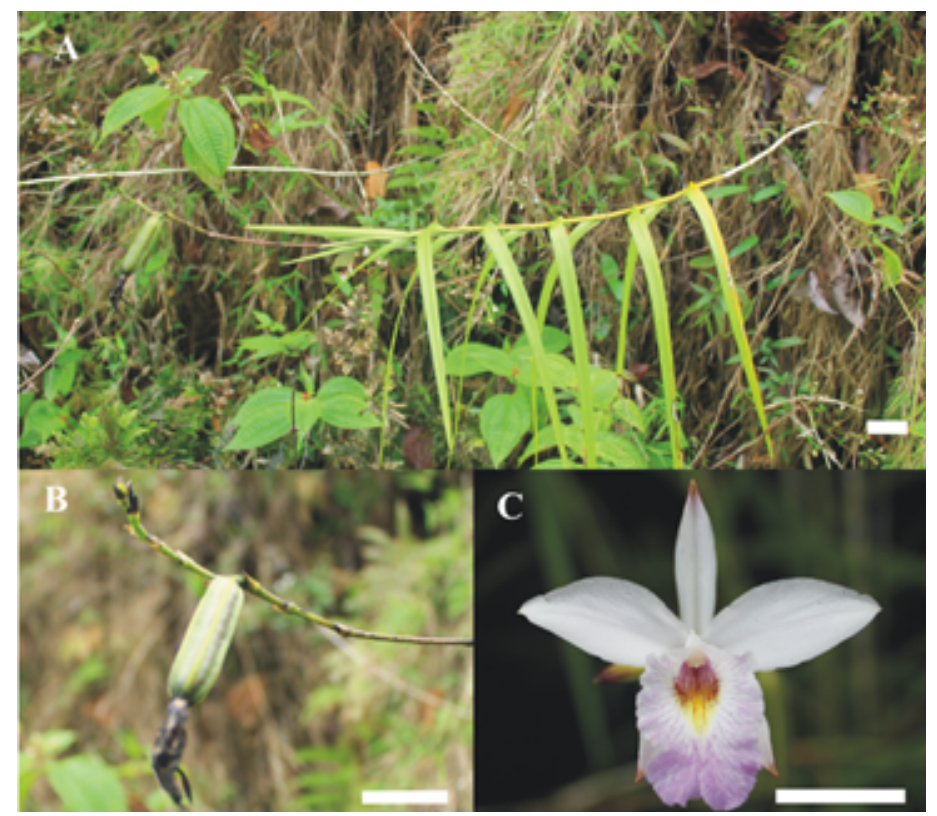

Figure 01. Morphology of bamboo orchid from Menoreh Hills, Kulonprogo. (A) habitat, habitus, stems, leaves and inflorescence; (B) fruit and (c) flowers (bars: $\mathbf{2}$ cm) 
A. graminifolia from the Kottavasal Hills, India (Mathew and George, 2015) has sepals, petals, and labellum with a dominant color of purple. Median base of the labellum is white. A. graminifolia from the Wilis Hills, East Java (Yulia \& Pa'i, 2011) has white sepals, white petals, and dominant white labellum with a very thin purple tip. Base of the labellum is yellow with a brownish red stripe motif. A. graminifolia from Banyunganti, Kulonprogo has white sepals, petals and labellum. Some people call it the alba variety. A. graminifolia var. revoluta from Eastern Khasi Hills and West Jaintia Hills, India (Kumar et al., 2014) has sepals and petals dominated by white with purple stripes in the middle. Labellum is dominated by a dark purple color at the tip, a yellow base with a brownish-red stripe motif, and white with purple-striped. A. graminifolia var. revoluta from West Kalimantan (Yorifuji et al., 2015) has purple sepals and petals and dark purple color at the edges and base labellum. Median portion of labellum is white. A. graminifolia var. graminifolia from West Kalimantan (Yorifuji et al., 2015) has white sepals, white petals, and dominant white labellum with dark purple tips. Median labellum is white and yellow, while the base is brownish red. In addition, there are A. graminifolia with purple-pink labellum with an orange-yellow median section and pink pale-white sepals and petals (Devika and Nagulan, 2018). Emergence of variations in A. graminifolia population can be caused by differences in geographical location, habitat, environmental parameters, and others.

Variations that appear in A. graminifolia population indicate that in the process of identifying a taxon, it cannot be done using only morphological characters in all plant species. Another approach that can be used to support morphological characters and complete the identification process is molecular approach. One of the molecular methods is cytogenetics with the study of chromosomes. Differences in the content of chromosomes describe differences in the genetic content of an organism. Individuals within same species also have the same number of chromosomes. Different species within same genera have a different number of chromosomes. Shape, size and number of chromosomes of each species are always fixed, so that, it can be used as a reference in taxonomy, knowing diversity, relationship, and evolution, although in certain circumstances variations can occur (Crowder, 1990; Setyawan and Sutikno, 2000; Suliartini et al., 2004).

Arundina belongs to the subfamily Epidendroideae. Members of this subfamily have diploid chromosome numbers $2 \mathrm{n}=28$, 30, 32, 34, 36, 38, 40, 42, 46, 48, 50 (Davina et al., 2009). A. graminifolia has the number of chromosomes $2 \mathrm{n}=40$, but also, there are those who reveal the number of $2 n=32$ (Lee, 1987). According to Lee (1987) A. graminifolia has 40 chromosomes $(2 \mathrm{n})$. Based on the number of A. graminifolia chromosomes obtained from The Chromosome Counts Database (CCDB) (Rice et al., 2015) most of $A$. graminifolia has a basic chromosome number of $\mathrm{n}=20$. In diploid conditions there are many variations, namely $2 n=32,38,40,42$; but most of them have a chromosome number of $2 n=40(C C B D, 2021)$. Based on observations in the root tip cells of bamboo orchid from Kulonprogo in mitosisprometaphase, there are 20 chromosomes $(2 \mathrm{n})$ (Figure $02 \mathrm{~A}$ ). Based on the literature, bamboo orchids from Kulonprogo should have 40 chromosomes (2n) if it is classified as A. graminifolia species according to the identification results based on morphological characters, but in this study, different results were found. The difference in the number of chromosomes indicates that the two individuals are different species, although morphologically, the bamboo orchid from Kulonprogo has similarities with the species $A$. graminifolia.

Karyotype is a chromosome arrangement that is sequential according to length and shape. Each species has a different shape and number of chromosomes, so karyotype formula for each species is also different. Chromosome identification is usually done in the prometaphase because the size of the chromosome is much longer and the structure of the chromosome appears clearer than in the metaphase (Parjanto et al., 2003). Based on karyotype analysis, bamboo orchids collected from Kulonprogo have the karyotype formula 
$2 \mathrm{n}=2 \mathrm{x}=20=16 \mathrm{~m}+4 \mathrm{sm}$ (Figure 02 B). There are 20 chromosomes in this plant with 4 submetacentric chromosomes (chromosome numbers 1-4) and 16 metacentric chromosomes (chromosome numbers 5-20). Based on absolute arm length of the chromosome $(\mathrm{p}+\mathrm{q})$, chromosome number 1 has the longest size $(1.64 \mu \mathrm{m})$ and chromosome number 20 has the shortest size $(0.55 \mu \mathrm{m})$ (Figure $02 \mathrm{~B}$ ). According to Singh (1999), karyotype formula of bamboo orchid is classified as an asymmetric karyotype, because there are variations in chromosome shape, namely, the presence of metacentric and submetacentric form in the karyotype formula. Asymmetric karyotypes are considered more advanced than symmetric karyotypes, because in addition to the diversity of shapes, asymmetric karyotypes also show the results of new cultivation or domestication of these plants.

Idiogram is a graphic image of a karyotype showing the haploid chromosome complement of a species that functions to determine the relative differences in chromosomes. Based on the bamboo orchid idiogram from Kulonprogo (Figure 03), it can be seen that the plant has a short arm size (p) and long arm (q) that varies on each pair of chromosomes that is $0.27-0.59$ $\mu \mathrm{m}$ and 0.3-1.025 $\mu \mathrm{m}$ (Table 02). The relative length of chromosomes also varies, ranging from 0.57-1.615 $\mu \mathrm{m}$ (Table 02). Chromosome pairs number 1 and 2 have submetacentric chromosome shapes and chromosome pairs numbers 3 to 10 have metacentric shapes (Table 02).

The emergence of variations in morphological character(flower)of A.graminifoliacanbecaused by differences in microclimate conditions which include temperature (Dahlgren et al., 2007; van der Kooi et al., 2019), humidity, light intensity, aeration, substrate, and diversity of symbiotic microbial (mycorrhiza, endophytic bacteria and others). The difference in microclimates is caused by differences in geographical location, habitat and others. Morphological character differences can be reversible or plastic and irreversible. Reversible or plasticity arises due to differences in environmental conditions for plant survival mechanism but does not affect genetic material or genotype (Cach-Perez et al., 2018). This condition in taxonomy refers to the forma category. Irreversible traits, mean changes in morphological characters caused by the isolation process, will be derived and affect the change in genetic material, so that, it becomes a sign of the speciation process (Lowry, 2012).

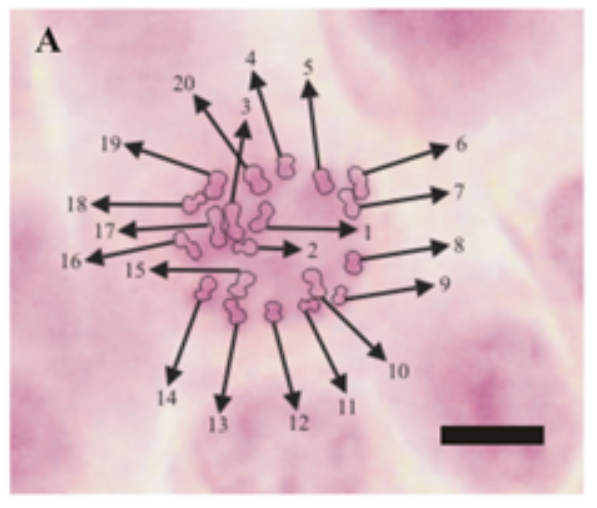

\section{B}

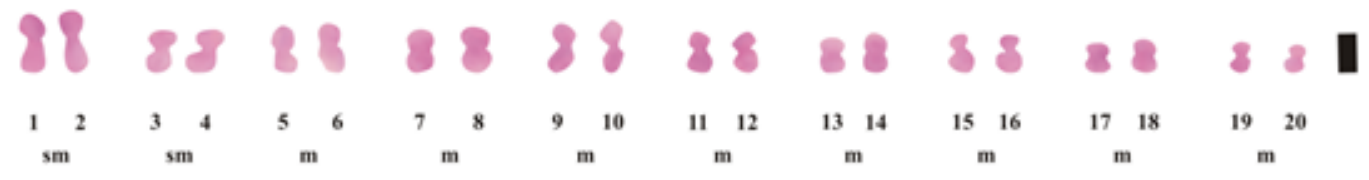

Figure 02. Visualization of bamboo orchid chromosomes. (A) Visualization of prometaphase in bamboo orchid cell cycle from Menoreh Hills, Kulonprogo with chromosomes total $2 \mathrm{n}=\mathbf{2 0}$ (bar: $5 \mu \mathrm{m}$ ) and (B) Karyotype of bamboo orchid chromosomes from Menoreh Hills, Kulonprogo (bar: $1 \mu \mathrm{m}$ ) 


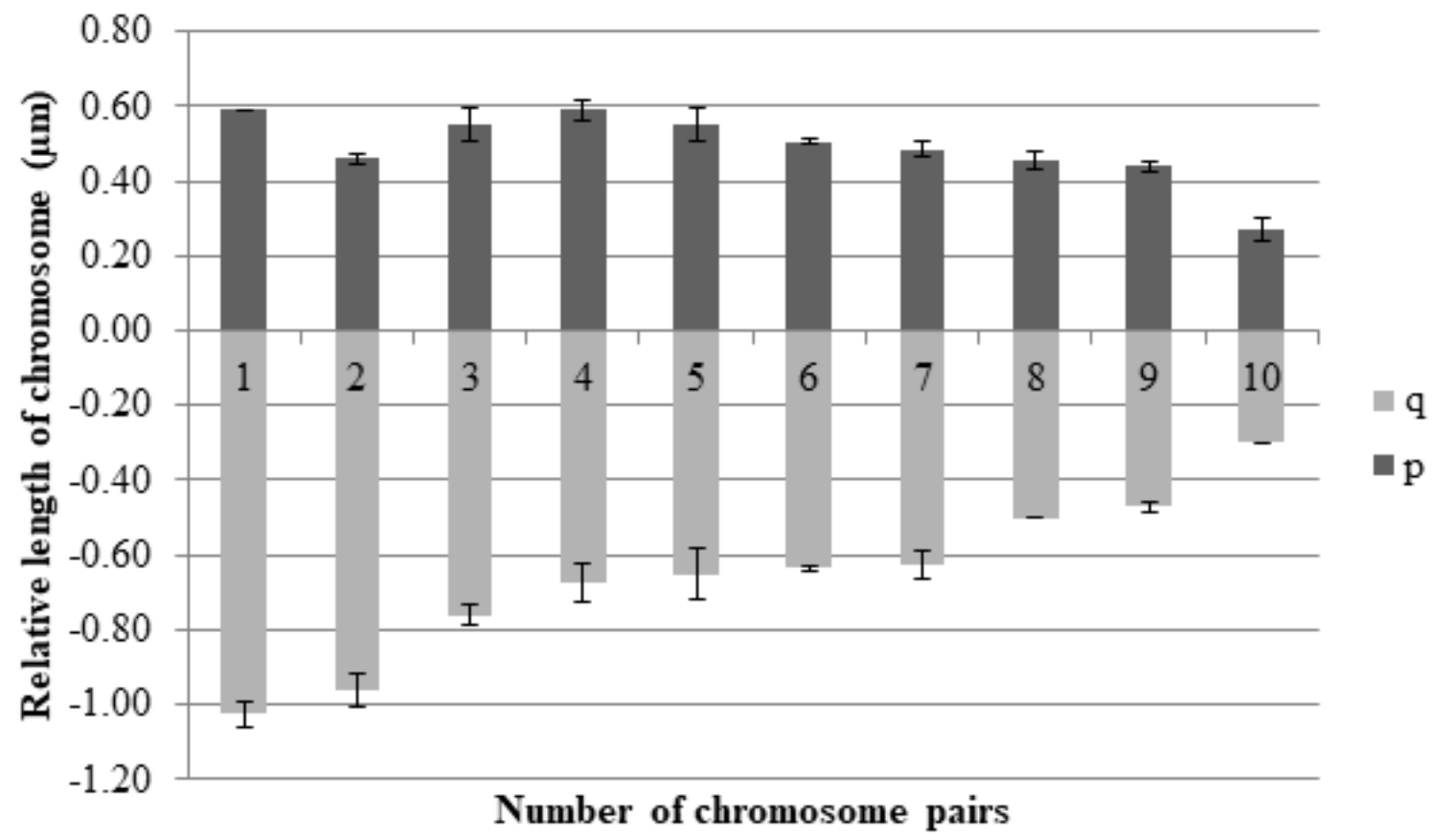

Figure 03. Idiogram of bamboo orchids from Menoreh Hills, Kulonprogo

Table 02. Chromosome shape determination of each pair of bamboo orchid chromosomes from Menoreh Hills, Kulonprogo

\begin{tabular}{|c|c|c|c|c|c|}
\hline $\begin{array}{c}\text { Number } \\
\text { chromosome } \\
\text { pairs }\end{array}$ & $\begin{array}{c}\text { Relative } \\
\text { length of } \\
\text { short arms/ } \\
\text { p }(\mu \mathrm{m}) \\
\end{array}$ & $\begin{array}{c}\text { Relative } \\
\text { length of } \\
\text { long arms/ q } \\
(\mu \mathrm{m}) \\
\end{array}$ & $\begin{array}{c}\text { Relative length } \\
\text { of chromosomes/ } \\
\mathbf{p}+q(\mu \mathrm{m})\end{array}$ & $\begin{array}{l}\text { Centromere } \\
\text { Index (CI) }\end{array}$ & $\begin{array}{c}\text { Chromosome } \\
\text { shapes }\end{array}$ \\
\hline 1 & $0.590 \pm 0.0$ & $1.025 \pm 0.0354$ & $1.615 \pm 0.035355$ & 36.533 & $\mathrm{sm}$ \\
\hline 2 & $0.460 \pm 0.0141$ & $0.960 \pm 0.0424$ & $1.420 \pm 0.028284$ & 32.394 & $\mathrm{sm}$ \\
\hline 3 & $0.550 \pm 0.0424$ & $0.760 \pm 0.0283$ & $1.310 \pm 0.014142$ & 41.985 & $\mathrm{~m}$ \\
\hline 4 & $0.590 \pm 0.0282$ & $0.675 \pm 0.0495$ & $1.265 \pm 0.021213$ & 46.640 & $\mathrm{~m}$ \\
\hline 5 & $0.550 \pm 0.0424$ & $0.650 \pm 0.0707$ & $1.200 \pm 0.028284$ & 45.833 & $\mathrm{~m}$ \\
\hline 6 & $0.505 \pm 0.0070$ & $0.635 \pm 0.0071$ & $1.140 \pm 0.014142$ & 44.298 & $\mathrm{~m}$ \\
\hline 7 & $0.485 \pm 0.0212$ & $0.625 \pm 0.0354$ & $1.110 \pm 0.014142$ & 43.694 & $\mathrm{~m}$ \\
\hline 8 & $0.455 \pm 0.0212$ & $0.500 \pm 0.0$ & $0.955 \pm 0.021213$ & 47.644 & $\mathrm{~m}$ \\
\hline 9 & $0.440 \pm 0.0141$ & $0.470 \pm 0.0141$ & $0.910 \pm 0.014142$ & 48.352 & $\mathrm{~m}$ \\
\hline 10 & $0.270 \pm 0.0283$ & $0.300 \pm 0.0$ & $0.570 \pm 0.028284$ & 47.368 & $\mathrm{~m}$ \\
\hline
\end{tabular}


Menoreh Hills have karst soil types (Basri et al., 2019) which can lead to variations due to mineral content and microbial diversity in them that affect the growth and development of orchids. According to Setiaji et al. (2018) bamboo orchids (A. graminifolia) in Yogyakarta, besides being found in Purwosari Village, Kulonprogo, can also be found in the Southern Slope of Mount Merapi, Sleman. Emergence of variations in A. graminifolia flowers can be caused by the natural selection process that triggers the emergence of variations at the level of infraspecies, so that new taxa appear under A. graminifolia species such as revoluta varieties (Kumar et al., 2014; Yorifuji et al., 2015), graminifolia varieties (Yorifuji et al., 2015) and other members of A. graminifolia species which have not been revealed and have not been studied.

MenorehHills is a long karst area and it consists of high diversity of orchids (Setiaji et al., 2018). A. gramiinifolia is an orchid that resembles weeds. It has a resistance to environmental damage and habitat fragmentation like other orchids with a similar live form. This ability affects the process of distribution and colonization in a habitat. The process of distribution and colonization is also influenced by genetic and evolutionary processes, where the genetic structure of orchid populations with these characteristics has not been studied much (Ueno et al., 2015). The population of $A$. graminifolia scattered in the Menoreh area has not been studied much so that genetic information about this species has not been found yet, including cytogenetic studies. Cytogenetic studies are important in taxonomic studies because each species has a different number and structure of chromosomes (Bolcun-Filas and Schimenti, 2012). Cytological studies play a role in studying the presence of morphological abnormalities (Samatadze et al., 2020), studying evolutionary processes (Lusinska et al., 2019), identification (Lukhtanov and Shapoval, 2017) and to study the diversity of a species (Bzdega et al., 2016 ).

In the CCDB database, Arundina species collected from India had 40 (2n) chromosomes (CCBD, 2021), as did those collected from Singapore and Malaysia (Lee, 1987). In the
Arundina population cultivated in China, it is known to have a chromosome number of 38 (2n) (CCBS, 2021). This shows that there is a genotypic variation in the Arundina population, in addition to variations in flower patterns (phenotypic variation). According to Lee (1987), one of the reasons that support the emergence of variations in the number of chromosomes in the Arundina genera is due to an unbalanced meiotic division. Irregular separation of homologous chromosomes in anaphase I, causes the appearance of abnormalities in the number and shape of chromosomes in individual offspring. This event can occur naturally, and cause variations in the number of chromosomes in Arundina. In general, most species of the Arundina genera have a chromosome number of 40 (2n) (CCBD, 2021). Therefore, the bamboo orchid from Menoreh which has a chromosome number of $20(2 n)$ is one of the variants of the Arundina population that arises due to abnormalities during meiosis or comes from a different ancestor from the Arundina population which has a chromosome number of $40(2 \mathrm{n})$. However, this still needs to be further confirmed, because not many studies have been done. Each species has a different number and shape of chromosomes. Morphologically, the bamboo orchid from Menoreh has the same character as the literature for A. graminifolia, but the number of chromosomes is different. Based on this result, bamboo orchids collected from Menoreh, Kulonprogo are likely to be potential cryptic species or new species of Arundina genera.

The chromosome preparation method used in this research was still conventional, so it needs further confirmation with more advanced methods such as Flourescence. In situ Hybridization (FISH) analysis, RAPD, ISSR, SSR, RFLP or sequencing as a correction tool and support the identification process. In the future, it needed for further testing with other molecular approaches to be able to carry out a perfect verification process in taxonomic field. This bamboo orchid can also be investigated in terms of its metabolite content to be developed as a medicine. Research says that rhizome $A$. graminifolia can be used to control bacterial activity. Root can be used to control diabetes, 
tumors, hyperliposis, and hepatitis (Debnath et al., 2016). Compound content of a plant can also vary depending on environment, habitat and growing substrate. Besides being able to be studied in the field of taxonomy, this orchid can also be developed in pharmacology sector. In the future, an effective and efficient strategy for cultivating this orchid needs to be developed to fulfill medicinal raw material in pharmacy sector.

\section{CONCLUSIONS}

Bamboo orchids from Menoreh Hills, Kulonprogo have white sepals and petals, with the edges of petals yellowish brown. Labellum is dominated by white color with thin purple lines on the edges, and base of labellum is yellow. Collected sample have a chromosome number $2 n=20$ with karyotype formula formed is $2 \mathrm{n}=2 \mathrm{x}=20=16 \mathrm{~m}+4 \mathrm{sm}$. Chromosome pairs number 1-2 have submetacentric shapes, while chromosome pairs number 3-10 have metacentric shapes. Bamboo orchid chromosome from Kulonprogo has an absolute length range from $0.55-1.64 \mu \mathrm{m}$, and relative length ranging from $0.57-1.615 \mu \mathrm{m}$. Bamboo orchids collected from Kulonprogo based on morphological characters have similarities with Arundina graminifolia species. Based on the number and karyotype of chromosomes, bamboo orchids from Kulonprogo differ from the basic number of chromosomes in A. graminifolia. The bamboo orchid from Menoreh can be said to be a new variant of the A. graminifolia population.

\section{ACKNOWLEDGEMENTS}

The authors declare that there is no conflict of interest regarding the publication of this paper. On this occasion the research group would like to thank to members of Biology Orchid Study Club (BiOSC) for their assistance in specimen collection and Yogyakarta orchids inventory in Kulonprogo.

\section{REFERENCES}

Basri, A.R., Putri, F., Kurniawan, F.Y., Mustika, N.D., and Semiarti, E. (2019). Diversity and conservation strategy of orchid species on karst land in Mudal River Park Ecotourism, Kulonprogo, Yogyakarta. International Journal of Advances in Science Engineering and Technology, 7(3), 6-10.

Bolcun-Filas, E. and Schimenti, J.C. (2012). Genetics of meiosis and recombination in mice. International Review of Cell and Molecular Biology, 298(1), 179-227. DOI: https://doi. org/10.1016/B978-0-12-394309-5.00005-5

BPTH (Balai Penelitian Tanaman Hias). (2007). Panduan karakterisasi tanaman hias anggrek. [Eng: Characterization guidelines for ornamental plants, orchid]. Balai Penelitian Tanaman Hias, Departemen Pertanian, Kementrian Pertanian Republik Indonesia, Jawa Barat. 1-39.

Bzdega, K., Janiak, A., Książczyk, T., Lewandowska, A., Gancarek, M., Sliwinska, E., and Tokarska-Guzik, B. (2016). A survey of genetic variation and genome evolution within the invasive Fallopia complex. PLOS ONE, 11(8), 1-23. DOI: https://doi.org/10.1371/journal. pone. 0161854

Cach-Perez, M.J., Andrade, J.L. and Reyes-Garcia, C. (2018). Morphophysiological plasticity in epiphytic bromeliads across a precipitation gradient in the Yucatan Peninsula, Mexico. Tropical Conservation Science, 11, 1-10. DOI: https://doi.org/10.1177/1940082918781926

CCBD. (2021). The Chromosome Counts Database (CCDB) version 1.58. http://ccdb.tau.ac.il/. 02.08.2021. 
Comber, J.B. (1990). Orchid of java. The Royal Botanic Garden Kew, London.

Crowder, L.V. (1990). Genetika tumbuhan. [Eng: Plant genetics]. Gadjah Mada University Press, Yogyakarta.

Dahlgren, J.P., Zeipei, H.v. and Ehrlen, J. 2007. Variation in vegetative and flowering pheonolgy in a forest herb caused by environmental heterogeneity. American Journal of Botany, 94(9), 1570-1576. DOI: https://doi.org/10.3732/ajb.94.9.1570

Davina, J.R., Grabiele, M., Cerutti, J.C., Hojsgaard, D.H., Almada, R.D., Insaurralde, I.S. and Honfi, A.I. (2009). Chromosome studies in Orchidaceae from Argentina. Genetics and Molecular Biology, 32(4), 811-821. DOI: https://doi.org/10.1590/S1415-47572009005000089

Debnath, B., Sarma, D., Paul, C. and Debnath, A. (2016). Arundina graminifolia (D.Don) Hocr (Orchidaceae) a new addition to the flora of Tripura. Asian Journal Plant Science Research, 6(3), 28-31.

Delgado-Davila, R., Marten-Rodriguez, S. and Huerta-Ramos, G. (2016). Variation in floral morphology and plant reproductive success in four Ipomoea species (Convolvulaceae) with contrasting breeding systems. Plant Biology, 18(6), 903-912. DOI: https://doi.org/10.1111/ plb.12507

Devika, J.M. and Nagulan, V. (2018). Floral biology, pollination and breeding mechanism in bamboo orchid (Arundina graminifolia (D.Don) Hochr. growing in Meghalaya, North East India. Research Journal of Science and IT Management, 7(10), 20-26.

Fajriyah, H.N. (2011). Keberadaan fungi mikoriza di dalam jaringan akar Dendrobium crumenatum Sw., Dendrobium cucullatum R.Br., dan Dendrobium anosmum Lindl. [Eng: The presence of mycorrhizal fungi in root tissue of Dendrobium crumenatum Sw., Dendrobium cucullatum R.Br., and Dendrobium anosmum Lindl]. Undergraduate Thesis, Universitas Indonesia, Jakarta.

Herrera, C.M. (1995). Microclimate and individual variation in pollinators: flowering plants are more than their flowers. Ecology, 76(5), 1516-1524. DOI: https://doi.org/10.2307/1938153

Kumar, R., Singh, S.K., Sharma, S., Verma, D. and Rao, C.S. (2014). Recollection of Arundina graminifolia var. revoluta (Orchidaceae) from India. Richardiana, XV, 128-134.

Lawrence, G.H.N. (1968). Taxonomy of Vascular Plants. The Millan Company, New York.

Lee, Y.H. (1987). Cytological studies on Arundina graminifolia (Orchidaceae). Cytologia, 52(2), 267-273. DOI: https://doi.org/10.1508/cytologia.52.267

Levan, A., Fredga, K. and Sandberg, A.A. (1964). Nomenclature for centromic position on chromosomes. Institute of Genetics, Lund, Sweeden.

Lowry, D.B. (2012). Ecotypes and the controversy over stages in the formation of new species. Biological Journal of the Linnean Society, 106(2), 241-257. DOI: https://doi.org/10.1111/ j.1095-8312.2012.01867.x

Lukhtanov, V.A., and Shapoval, N.A. (2017). Chromosomal identification of cryptic species 
sharing their DNA barcodes: Polyommatus (Agrodiaetus) antidolus and P. (A.) morgani in Iran (Lepidoptera, Lycaenidae). Comparative cytogenetics, 11(4), 759-768. DOI: https://doi. org/10.3897/CompCytogen.v11i4.20876

Lusinska, J., Betekhtin, A., Lopez-Alvarez, D., Catalan, P., Jenkins, G., Wolny, E., and Hasterok, R. (2019). Comparatively barcoded chromosomes of Brachypodium perennials tell the story of their karyotype structure and evolution. International journal of molecular sciences, 20(22), 1-19. DOI: https://doi.org/10.3390/ijms20225557

Mathew, J. and George, K.V. (2015). Checklist of orchids of kottavasal hills in Achancoil Forests, Southern Western Ghats, (Kollam, Kerala), India. Journal of Threatened Taxa, 7(10), 76917696. DOI: http://dx.doi.org/10.11609/JoTT.o3859.7691-6

Meena, M., Swapnil, P., Barupal, T., Sharma, K. and Jain, T. (2019). Phenotype. In: Encyclopedia of Animal Cognition and Behavior. (Vonk, J. and Shackelford, T. Eds.). Springer, Cham.

Nathewet, P., Yanagi, T., Hummer, K.E., Iwatsubo, Y. and Sone, K. (2009). Karyotype analysis in wild diploid, tetraploid and hexaploid strawberries, Fragaria (Rosaceae). Cytologia, 74(3), 355-364. DOI: https://doi.org/10.1508/cytologia.74.355

Nuraliev, M.S., Sokoloff, D.D., Karpunina, P.V. and Oskolski, A.A. (2019). Patterns of diversity of floral symmetry in Angiosperms: a case study of the Order Apiales. Symmetry, 11(473), 1-26. DOI: https://doi.org/10.3390/sym11040473

Ueno, S., Rodrigues, J.F., Alves-Pereira, A., Pansarin, E.R., and Veasey, E.A. (2015). Genetic variability within and among populations of an invasive, exotic orchid. AoB PLANTS, 7(plv077), 1-13. DOI: https://doi.org/10.1093/aobpla/plv077

Parjanto, Moeljopawiro, S., Artama, W.T. and Purwantoro, A. (2003). Kariotipe kromosom salak. [Eng: Chromosome Karyotype of Zallaca]. Zuriat, 14(2), 21-28.

Rice, A., Glick, L., Abadi, S., Einhorn, M., Kopelman, N.M., Salman-Minkov, A., Mayzel, J., Chay, O., \& Mayrose, I. (2015). The Chromosome Counts Database (CCDB) - a community resource of plant chromosome numbers. New Phytologist, 206(1), 19-26. DOI: https://doi. org/10.1111/nph.13191

Samatadze, T.E., Yurkevich, O.Y., Hazieva, F.M., Konyaeva, E.A., Morozov, A.I., Zoshchuk, S.A., Amosova, A.V., \& Muravenko, O.V. (2020). Agro-morphological, microanatomical and molecular cytogenetic characterization of the medicinal plant Chelidonium majus L. Plants (Basel, Switzerland), 9(10), 1-17. DOI: https://doi.org/ 10.3390/plants9101396

Setiaji, A., Muna, A., Jati, F.P., Putri, F. and Semiarti, E. (2018). Keanekaragaman anggrek di Daerah Istimewa Yogyakarta. [Eng: Orchid Diversity in Special Region of Yogyakarta]. Prosiding Seminar Nasional Masyarakat Biodiversitas Indonesia, 4(1), 63-68. DOI: https:// doi.org/10.13057/psnmbi/m040110

Setyawan, A.D. and Sutikno. (2000). Karyotipe kromosom pada Allium sativum L. (bawang putih) dan Pisum sativum L. (kacang kapri). [Eng: Chromosome karyotype in Allium sativum L. (garlic) and Pisum sativum L. (peas)]. Biosmart, 1(1), 20-27.

Singh, R.J. (1999). Plant systematic. Science Publisher, Inc, New York. 
Suliartini N., Purwantoro, A. and Sulistyaningsih, E. (2004). Keragaman genetik dalam spesies Caladium bicolor berdasarkan analisis kariotipe. [Eng: Genetic diversity in Caladium bicolor species based on kariotype analysis]. Agrosains, 17(2), 235-244.

Swarts, D.N. and Dixon, W.D. (2009). Terrestrial orchid conservation in the age of extinction. Annals of Botany, 104, 543-556. DOI: https://doi.org/10.1093/aob/mcp025

Van der Kooi, C.J., Kevan, P.G. and Koski, M.H. (2019). The thermal ecology of flowers. Annals of Botany, 124(3), 1-11. DOI: https://doi.org/10.1093/aob/mcz073

Yorifuji, E., Ishikawa, N., Okada, H. and Tsukaya, H. (2015). Arundina graminifolia var. revoluta (Arethuseae, Orchidaceae) has fern-type rheophyte characteristics in the leaves. Journal of Plant Research, 128(2), 239-247. DOI: https://doi.org/10.1007/s10265-014-0689-0

Yulia, N.D. and Pa'i. (2011). Asosiasi dua jenis anggrek tanah (Arundina graminifolia dan Spathoglottis plicata) di sebagian kawasan Cagar Alam Gunung Picis, Pegunungan Wilis, Jawa Timur. [Eng: Association of two terrestrial orchids species (Arundina graminifolia and Spathoglottis plicata) in part of Mount Picis Nature Reserve area, Wilis Mountains, East Java]. Berkala Penelitian Hayati, 5A, 137-140. 